\title{
Comparative study between ondansetron vs Palonosetron for controlling postoperative nausea and vomiting.
}

\author{
Hasan $M^{1}{ }^{1}$, Islam $M^{2}$, Ara $A^{3}$, Fazilatunnesa ${ }^{4}$, Rahman $M A^{5}$, Sultana $M H^{6}$, Akhtar $S^{7}$
}

\begin{abstract}
Postoperative nausea and vomiting (PONV) is a major complication in patients who undergo surgery under general anaesthesia. Various drug regimens and antiemetic interventions have been tried from time to- time for prevention of PONV but with a variable success rate. The aim of the study is to compare between ondansetron vs Palonocstron for controlling postoperative nausea and vomiting. In this prospective study, 100 patients aged 18-60 years of ASA GRADE-I and II scheduled for undergoing surgery under general anaesthesia after taking informed written consent at a tertiary care hospital, were randomly divided into two groups of 50 each .Group-A was given palonosetron $75 \mu \mathrm{g}$ and Group-B was given ondansetron $4 \mathrm{mg}$. At 72 hours, nausea and vomiting were statistically significant between ondansetron and palonosetron groups. Postoperative side-effects such as headache, dizziness and drowsiness were not statistically significant between ondansetron and palonosetron groups. In conclusion, the antiemetic efficacy of palonosetron is similar to that of Ondansetron for preventing PONV during the first 24 hours after patients who undergo surgery under general anaesthesia. But after 72 hours, nausea and vomiting were statistically higher in ondansetron group than palonosetron group.
\end{abstract}

CBMJ 2017 July: Vol. 06 No. 02 P: 15-20

Key words: Postoperative nausea and vomiting, Ondansetron vs Palonosetron.

\section{Introduction}

Post-operative nausea and vomiting (PONV) is commonly seen in female patients undergoing abdominal surgeries under general anaesthesia. ${ }^{1}$ Postoperative nausea and vomiting (PONV) is a major complication in patients who undergo surgery under general anaesthesia. Various drug regimens and antiemetic interventions have been tried from time to- time for prevention of PONV but with a variable success rate. This study compares the safety and efficacy of ondansetron and palonosetron in preventing PONV in such patients. ${ }^{2}$ Post operative nausea and vomiting (PONV) is a common and distressing complication of surgery under general anesthesia. The incidence of PONV remains unacceptably high $(40-75 \%$ in the first 24 hours) following laparoscopic

PONV is defined as any nausea, retching or vomiting occurring during the first $24-48$ hours after surgery in inpatients. Though often temporary, it is unpleasant, with reported incidences of $30 \%$ in all post-surgical patients
1. *Dr. Muhammad Masud Hasan

Assistant Professor, Department of Anaesthesiology Community Based Medical College, Bangladesh

2. Dr. Md. Shafiqul Islam

Senior Consultant, Department of Surgery Mymensingh Medical College Hospital, Mymensingh, Bangladesh

3. Dr. Anjuman Ara

Associate Professor, Department of Anatomy Community Based Medical College, Bangladesh Mymensingh

4. Dr. Fazilatunnesa

Assistant professor, Department of Pathology Community Based Medical College, Bangladesh Mymensingh

5. Dr. Md. Ashiqur Rahman

Registrar, Department of ENT

Mymensingh Medical College Hospital

Mymensingh, Bangladesh

6. Dr. Mst. Habiba Sultana

Medical Officer, Department of Ophthalmology

Community Based Medical College Hospital

Bangladesh, Mymensingh

7. Dr. Sabiha Akhtar

Private Practitioner, Dhaka.

"Address of correspondence

Mobile: 01712524219

Email : 
and up to $80 \%$ in high-risk patients. ${ }^{5}$ In the recovery room $20 \%$ of patients suffer with nausea and $5 \%$ with vomiting while even thereafter, $50 \%$ suffer with nausea and $25 \%$ with vomiting. ${ }^{6}$

\section{Methods}

In this prospective study, 100 patients aged 18-60 years of ASA GRADE-I and II scheduled for surgery under general anaesthesia after taking informed written consent at a tertiary care hospital, were randomly divided into two groups of 50 each.Group-A was given palonosetron $75 \mu \mathrm{g}$ and Group-B was given ondansetron $4 \mathrm{mg}$. Exclusion criteria were pregnancy, use of corticosteroids or psychoactive drugs, $\mathrm{H} / \mathrm{O}$ alcohol or substance abuse and known hypersensitivity to any of study drugs. All patients were kept fasting for 6-8 hours and received Inj. Midazolam $1 \mathrm{mg}$, Inj. Fentanyl $2 \mu \mathrm{g} / \mathrm{kg}$ and Inj. Glycopyrrolate $0.2 \mathrm{mg}$ as premedication. On the operation table, routine monitoring (ECG, pulse oximetry, ETCO2, NIBP) was done and baseline vitals were recorded. An intravenous line was secured. The study drug was given 1 min before induction of anesthesia. Patients received randomly pre induction dose of either palonosetron $75 \mu \mathrm{g}$ IV (group-A) or ondansetron $4 \mathrm{mg}$ IV (group-B). Anesthesia was induced with Inj. Thiopentone $5-7 \mathrm{mg} / \mathrm{kg}$ IV. Tracheal intubation was facilitated by Inj. Succinyl choline $2 \mathrm{mg} / \mathrm{kg}$ IV. Anesthesia was maintained on $\mathrm{O} 2, \mathrm{~N} 2 \mathrm{O}$ and sevoflurane. Muscle relaxation was maintained with intermittent dose of Inj. Atracurium. Ventilation was controlled and adjusted to maintain the ETCO2 between $35-40 \mathrm{~mm}$ of $\mathrm{Hg}$. A nasogastric tube was inserted to make the stomach empty of air and other contents. All patients were received Inj. Diclofenac sodium $75 \mathrm{mg}$ IM for post operative analgesia. For the purpose of study, an episode of PONV denoted either a distinct spell of nausea, retching or vomiting. Nausea was defined as unpleasant sensation associated with awareness of urge to vomit. Retching was defined as an involuntary attempt to vomit but not actually productive of stomach contents. Vomiting was defined as the forceful expulsion of actual gastric contents. Complete response (free from emesis) was defined as no PONV and no need of any rescue medicine. The primary effectiveness measure was total number of PONV episodes in the 24 hours period following conclusion of surgery. Visual analogue score (as assessed using a $10 \mathrm{~cm}$ Nausea severity scale) at 2, 6 and 24 hours after completion of surgery was noted. Inj. Metoclopramide $10 \mathrm{mg}$ IV was given as a rescue antiemetic when episodes of PONV occurred or at VAS $>5$ or on demand. Safety of the study drugs was assessed by monitoring vital signs, $\mathrm{O} 2$ saturation, ECG and examination and asking the patients for adverse events for 24 hours following surgery. The results were expressed in mean $\pm S D$ and number (\%).

\section{Result}

Age, sex, ASA grade, weight, duration of surgery and duration of anesthesia were not statistically significant between ondansetron and palonosetron groups (Table 1). At 72 hour, nausea and vomiting were statistically significant between ondansetron and palonosetron groups (Table 2). Postoperative side-effects such as headache, dizziness and drowsiness were not statistically significant between ondansetron and palonosetron groups (Table 3 ).

Table-1 : Demographic characteristic of the study patients

\begin{tabular}{|c|c|c|c|c|c|}
\hline \multirow{2}{*}{\begin{tabular}{l|}
$\begin{array}{c}\text { Demographic } \\
\text { characteristics }\end{array}$ \\
Sex (Male/ \\
Female)
\end{tabular}} & \multicolumn{2}{|c|}{$\begin{array}{l}\text { Ondansetron } \\
\qquad(n=50)\end{array}$} & \multicolumn{2}{|c|}{$\begin{array}{l}\text { alonosetron } \\
(n=50)\end{array}$} & \multirow{2}{*}{$\frac{p \text { value }}{{ }^{\mathrm{a}} 0.56^{\mathrm{ns}}}$} \\
\hline & 8 & 142 & 6 & 144 & \\
\hline ASA grade $(I / I I)$ & 40 & $/ 10$ & 42 & 18 & ${ }^{\mathrm{a}} 0.60^{\mathrm{ns}}$ \\
\hline $\begin{array}{l}\text { Age in years } \\
\text { (Mean } \pm S D)\end{array}$ & 38.4 & \pm 10.4 & 40.3 & \pm 12.1 & ${ }^{b} 0.40^{n s}$ \\
\hline $\begin{array}{l}\text { Weight in } \mathrm{kg} \\
\text { (Mean } \pm \text { SD) }\end{array}$ & 61.0 & \pm 9.4 & 58.2 & \pm 10.7 & $0.16^{\mathrm{ns}}$ \\
\hline $\begin{array}{l}\text { Duration of } \\
\text { surgery in mins } \\
\text { (Mean } \pm \text { SD) }\end{array}$ & 64.9 & \pm 33.8 & 66.7 & \pm 32.9 & ${ }^{b} 0.78^{\text {ns }}$ \\
\hline $\begin{array}{l}\text { Duration of } \\
\text { anesthesia in } \\
\text { mins (Mean } \pm S D \text { ) }\end{array}$ & 110.3 & \pm 29.4 & 114.7 & \pm 32.9 & ${ }^{b} 0.48^{\text {ns }}$ \\
\hline
\end{tabular}

ns $=$ not significant

${ }^{\mathrm{a}} \mathrm{P}$ value reached from chi square test

${ }^{\mathrm{b}} \mathrm{P}$ value reached from unpaired t-test 
Table-2: Incidence of postoperative nausea and vomiting (PONV) and need for rescue antiemetics.

\begin{tabular}{|l|c|c|c|c|c|}
\hline $\begin{array}{l}\text { Demographic } \\
\text { characteristics }\end{array}$ & \multicolumn{2}{|c|}{$\begin{array}{c}\text { Ondansetron } \\
(\mathrm{n}=50)\end{array}$} & \multicolumn{2}{|c|}{$\begin{array}{c}\text { Palonosetron } \\
(\mathrm{n}=50)\end{array}$} & $p$ value \\
\hline $0-2$ hour & & & & & \\
\hline Nausea & 10 & 20.0 & 7 & 14.0 & $0.424^{\mathrm{ns}}$ \\
\hline Vomiting & 2 & 4.0 & 2 & 4.0 & $0.691^{\mathrm{ns}}$ \\
\hline PONV & 12 & 24.0 & 7 & 14.0 & $0.202^{\mathrm{ns}}$ \\
\hline $\begin{array}{l}\text { Rescue } \\
\text { antiemetics }\end{array}$ & 4 & 8.0 & 3 & 6.0 & $0.500^{\mathrm{ns}}$ \\
\hline 0-24 hour & & & & & \\
\hline Nausea & 18 & 36.0 & 9 & 18.0 & $0.043^{\mathrm{s}}$ \\
\hline Vomiting & 7 & 14.0 & 4 & 8.0 & $0.338^{\mathrm{ns}}$ \\
\hline PONV & 21 & 42.0 & 13 & 26.0 & $0.091^{\mathrm{ns}}$ \\
\hline $\begin{array}{l}\text { Rescue } \\
\text { antiemetics }\end{array}$ & 10 & 20.0 & 9 & 18.0 & $0.799^{\mathrm{ns}}$ \\
\hline $0-72$ hour & & & & & \\
\hline Nausea & 25 & 50.0 & 15 & 30.0 & $0.041^{\mathrm{s}}$ \\
\hline Vomiting & 11 & 22.0 & 4 & 8.0 & $0.049^{\mathrm{s}}$ \\
\hline PONV & 27 & 54.0 & 19 & 38.0 & $0.108^{\text {ns }}$ \\
\hline $\begin{array}{l}\text { Rescue } \\
\text { antiemetics }\end{array}$ & 15 & 30.0 & 14 & 28.0 & $0.826^{\text {ns }}$ \\
\hline
\end{tabular}

$\mathrm{s}=$ significant, $\mathrm{ns}=$ not significant

$P$ value reached from chi square test

Table-3: Incidence of adverse events.

\begin{tabular}{|l|c|c|c|c|l|}
\hline \multicolumn{1}{|c|}{$\begin{array}{c}\text { Adverse } \\
\text { events }\end{array}$} & \multicolumn{2}{|c|}{$\begin{array}{c}\text { Ondansetron } \\
(n=50)\end{array}$} & \multicolumn{2}{c|}{$\begin{array}{c}\text { Palonosetron } \\
(n=50)\end{array}$} & $p$ value \\
\hline Dizziness & 12 & 24.0 & 8 & 16.0 & $0.31^{\text {ns }}$ \\
\hline Headache & 10 & 20.0 & 7 & 14.0 & $0.42^{\text {ns }}$ \\
\hline Drowsiness & 5 & 10.0 & 6 & 12.0 & $0.74^{\text {ns }}$ \\
\hline
\end{tabular}

ns= not significant

$P$ value reached from chi square test

\section{Discussion}

In present study observed that the age, sex, ASA grade, weight, duration of surgery and duration of anesthesia were not statistically significant between ondansetron and palonosetron groups. In study of Singh et al. ${ }^{7}$ observed that the baseline demographic profile and clinical characteristics were comparable between both the groups with no statistically significant difference between them ( $p$-value >0.05). The incidence of PONV is associated with many factors like age and gender (female gender, younger age increase the risk of PONV), history of motion sickness or PONV, smoking status (smoking decreases the risk of PONV), postoperative opioid use, type and duration of surgery, anaesthesia and ambulation. ${ }^{8,9}$ These factors were comparable between both groups in the present study. Singh et al. ${ }^{10}$ there were no statistically significant differences between the two groups in terms of demographic characteristics namely age, sex, weight, ASA status, duration of anaesthesia and surgery. The duration of anaesthesia and surgery has a bearing on post operative nausea and vomiting as prolonged duration of surgery will increase the incidence of post operative nausea and vomiting, hence increasing the requirement of antiemetic. $^{11,12}$

In this study observed that at 72 hours, nausea and vomiting were statistically significant between ondansetron and palonosetron groups. Antiemetic efficacy of palonosetron is similar to that of Ondansetron for preventing PONV during the first 24 hours after laparoscopic cholecystectomy. It is a first approved for the prevention of chemotherapy induced nausea and vomiting. It has greater binding affinity and longer biological half time than ondansetron. ${ }^{13}$ The mechanism of its action on PONV is similar to ondansetron. Kovak et al. ${ }^{14}$ found that $75 \mu \mathrm{g}$ palonosetron is more effective dose for the prevention of PONV after major gynecological laparoscopic surgery than $25 \mu \mathrm{g}$ or $50 \mu \mathrm{g}$ dose. So we selected dose of palonosetron of $75 \mu \mathrm{g}$. Aspinall and Goodman ${ }^{15}$ found that in randomized controlled trial day care surgery, single pre-induction iv dose of palonosetron $75 \mathrm{mcg}$ proved to be superior to ondansetron $4 \mathrm{mg}$ in terms of numbers of subjects experiencing PONV episodes and the dose of rescue antiemetic required. The probable cause of early postoperative vomiting could be the use of volatile general anaesthetics. ${ }^{12}$ Vomiting in these patients could be due to longer surgical procedures under volatile general anaesthetics and nitrous oxide leading to prolonged exposure to them. ${ }^{11}$ Moon et al. ${ }^{16}$ study observed that overall, PONV incidence during the $\mathbf{2 4}$ hour after surgery was lower in the palonosetron group compared with the ondansetron group ( $42 \%$ vs $62 \%, \mathrm{P}=0.045$ ). There was no significant difference between the groups during the first 2 hour after surgery. On the other hand, the incidence of nausea 
and vomiting was significantly lower in the palonosetron group than in the ondansetron group 2-24 hour after surgery. Laparoscopic surgery has decreased the morbidity associated with cholecystectomy and has become an accepted procedure for symptomatic cholelithiasis. ${ }^{17}$ However, high incidence of PONV (53-72\%) is still been reported in patients undergoing this procedure. ${ }^{18}$ Singh et al. ${ }^{7}$ found that the incidence of nausea was significantly lower in the palonosetron group than in the ondansetron group during the 12-24 hour and over all $0-24$ hour time interval $(p<0.05)$. The frequency of vomiting was also less during the 12-24 hour and overall $0-24$ hour time interval although not statistically significant. The overall incidence of nausea (PONV Score 1) in 24 hours was more in ondansetron group than palonosetron group, this difference was statistically significant $(p=0.037)$. The incidence of post operative vomiting more than once in 24hours (PONV Score 3) was not statistically significant $(p=0.313)$ among group $\mathrm{O}$ \& group $\mathrm{P}$. Only $40 \%$ in group $\mathrm{O}$ while $73.3 \%$ in group $\mathrm{P}$ showed complete response (no nausea vomiting) to the study drug $(p=0.009)$, statistically significant. This is comparable with previous studies done by Nupur Chakravarty et al. ${ }^{19}$ and Shadangi et al. ${ }^{20}$. Requirement of rescue antiemetic was in $6(20 \%)$ patients in group $\mathrm{O}$ and in only 1 $(3.3 \%)$ patient in group $P \quad(p=0.044)$, statistically significant. ${ }^{10}$

In present study revealed that postoperative side-effects such as headache, dizziness and drowsiness were not statistically significant between ondansetron and palonosetron groups. Prakash et al. ${ }^{2}$ revealed that the rescue antiemetic (ondansetron $4 \mathrm{mg} \mathrm{IV} \mathrm{+}$ dexamethasone $5 \mathrm{mg} \mathrm{IV}$ ), was given to 9 $(30 \%)$ patients in group $O$ whereas to 5 $(16.6 \%)$ patients in group P. But no significant statistical difference was observed between both the groups $(p>0.5)$. The main side effects of 5-HT3 antagonists in the dosages used for PONV were headache and dizziness. ${ }^{21}$ There was no significant statistical difference between both the groups regarding safety profile of study drugs $(p>0.05)$. The effectiveness of ondansetron is comparable with palonosetron could be due to active metabolites of ondansetron (7-hydroxy or 8hydroxyondansetron) contributing to prolonged action of the drug. ${ }^{22}$ Risk factors for nausea and vomiting after laparoscopic surgery include a long period of carbon dioxide insufflation, ${ }^{23}$ gall bladder surgery, ${ }^{18}$ female $\operatorname{sex}^{24}$ and postoperative use of opioids. A single dose of palonosetron $(250 \mathrm{mcg}$ ) was found to be a superior antiemetic to ondansetron $(8 \mathrm{mg}$ ) in complete prevention of PONV after middle ear surgery during the first 24hour postoperative period. ${ }^{25}$ In a randomized controlled trial in day care surgery, single pre-induction $1 / \mathrm{V}$ dose of palonosetron $(75 \mathrm{mcg}$ ) proved to be superior to ondansetron $(8 \mathrm{mg})$ in terms of the number of subjects experiencing PONV episodes and the dose of rescue antiemetic required. ${ }^{26}$ The incidence of PONV has been found to be significantly lower with palonosetron than with ondansetron in gynecological laproscopic surgeries, although there were no significant differences in VAS scores for nausea. ${ }^{27}$ Singh et al. $^{7}$ found that complete response (no PONV and no rescue antiemetic) was more in the palonosetron group compared with the ondansetron group and the need for rescue antiemetics was less during $0-24$ hour time interval $(p<0.05)$. Incidence of adverse effects and patient satisfaction were comparable between the two groups. Singh et al. ${ }^{10}$ study showed that both palonosetron and ondansetron are known to have no serious adverse effects like short duration headache, constipation, dizziness. $2(6.6 \%)$ patients in both groups complained of headache, and 1 $(3.3 \%)$ patient in each group complained of dizziness. This difference was not significant statistically $(p=1.000)$. Apart from this no side effects were observed in patients of both the groups.

\section{Conclusion}

In conclusion it is revealed that antiemetic efficacy of palonosetron is similar to that of Ondansetron for preventing PONV during the first 24 hours after patients who undergo surgery under general anaesthesia.But after 
72 hour; nausea and vomiting were statistically higher in ondansetron group than palonosetron group.

\section{Reference}

1. Arya A, Jain S, Dulara SC, Gupta L. A comparison of ondansetron and palonosetron for prevention of post-operative nausea and vomiting in patients undergoing elective abdominal surgeries under general anaesthesia: A randomized double blind study. Indian Journal of Clinical Anaesthesia, 2015;2(2):82-85.

2. Prakash GB, Rao KU, Subash KR, Reddy KVC, Prasad KJ, Devi BV. Ondansetron versus palonosetron: a comparative study on efficacy and safety in prevention of postoperative nausea and vomiting. Int J Basic Clin Pharmacol 2016; 5:1269-1274.

3. Grover VK, Mathew PJ, Hegde H. Efficacy of orally disintegrating ondansetron in preventing postoperative nausea and vomiting after laparoscopic cholecystocomy: A randomized, double-blind placebo controlled study. Anaesthesia 2009;64:595-600.

4. Kloth $D D$. New pharmacologyc findings for the treatment of PONV and PDNV. Am J Health Syst Pharm 2009; 66:S11-18.

5. Gan TJ. Risk factors for postoperative nausea and vomiting. Anesth Analg. 2006;102:18841898.

6. Cohen MM, Duncan PG, DeBoer DP, Tweed WA. The postoperative interview: assessing risk factors for nausea and vomiting. Anesth Analg. 1994; 78:7-16.

7. Singh N, Raw BK, Kumar S, Monalisa, Mishra LS. Palonosetron vs Ondansetron for prevention of postoperative nausea and vomiting in patients undergoing laparoscopic cholecystectomy: A comparative study. IOSR Journal of Dental and Medical Sciences 2016; 15:45-49.

8. Watcha MF, White PF. Postoperative nausea and vomiting. Its etiology, treatment, and prevention. Anesthesiology 1992;77: 162-184.

9. Andrews PLR, Hawthorn J. The neurophysiology of vomiting. Clinical Gastroenterology 1988; 2: 141-168.

10. Singh T, Shah N, Patel C, Upadhayaya RM. A comparative study of prophylactic ondansetron versus palonosetron for post operative nausea and vomiting in middle ear surgeries. International Journal of Biomedical And Advance Research 2014:5:619-622.
11. Stadler $M$, Bardiau $F$, Seidel $L$, Albert $A$, Boogaerts JG. Difference in risk factors for postoperative nausea and vomiting. Anesthesiology. 2003; 98(1):46-52.

12. Apfel CC, Kranke P, Katz MH, Goepfert C, Papenfuss $T$, Rauch $S$, et al. Volatile anaesthetics may be the main cause of early but not delayed postoperative vomiting: $A$ randomized controlled trial of factorial design. $\mathrm{Br}$ J Anaesth. 2002; 88:659-68.

13. Aapro MS, Grunberg SM, Manikhas GM. A phase III, double-blind, randomized trial of palonosetron compared with ondansetron in preventing chemotherapy-induced nausea and vomiting following highly emetogenic chemotherapy. Ann Oncol. 2006; 17:1441-1449.

14. Kovak AL. Eberhart L, Kotasari J, Clerici G, Apfel C. A randomized double blind study fo evaluate the efficacy and safety of three different doses of palonosetron versus placebo in preventing post operative nausea and vomiting over a 72 hrs period. Anaesth Analg 2008; 107:439-444.

15. Aspinall RL, Goodman NW. Denial of effective treatment and poor quality of clinical Information in placebo controlled trials of ondansetron for postoperative nausea and vomiting: $A$ review of published trials. Br Med J 1995; 311:844-846.

16. Moon YE, Joo J, Kim JE, Lee Y. Anti-emetic effect of ondansetron and palonosetron in thyroidectomy: a prospective, randomized, double-blind study. British Journal of Anaesthesia 2012; 108(3): 417-422.

17. Sandor J, Sandor A, Zaborszky A, Megyaszai S, Benedek G, Szeberin Z. Why laparoscopic cholecystectomy today?. Surg Today. 1996; 26:556-560.

18. Naguib $M$, el Bakry AK, Khoshim MH, Channa $A B$, el Gammal M, el Gammal K. Prophylactic antiemetic therapy with ondansetron, tropisetron, granisetron and metoclopramide in patients undergoing laparoscopic cholecystectomy: A randomized, double-blind comparison with placebo. Can J Anaesth. 1996; 43:226-231.

19. Chakravarty N, Raghuwanshi SK. Comparison between efficacy of palonosetron and ondansetron in postoperative nausea and vomiting in middle ear surgery: $A$ randomized double blind study: Int J Pharm Bio Sci 2013; 4(4):67-74. 
20. Shadangi BK, Agrawal J, Pandey R, Kumar A, Jain S, Mittal R. A prospective, randomized, double-blind, comparative study of the efficacy of intravenous ondansetron and palonosetron for prevention of postoperative nausea and vomiting. Anaesth Pain \& Intensive Care 2013; 17(1):55-58.

21. Kovac AL. Prevention and treatment of postoperative nausea and vomiting. Drugs. 2000; 59:213-43.

22. Pritchard JF. Ondansetron metabolism and pharmacokinetics. Semin Oncol. 1992; 19/410):9-15.

23. Fredman $B$, Jedeikin $R$, Olsfanger $D$, Flor $P$, Gruzman A. Residual pneumoperitoneum: $A$ cause of postoperative pain after laparoscopic cholecystectomy. Anesth Analg. 1994; 79:152154.

24. Mraovic B, Jurioic T, Kogler-Majeric $V$, Sustic $A$. Intraperitoneal bupivicaine for analgesia after laparoscopic cholecystectomy. Acta Anaesthesiol Scand. 1997; 41:193-196.
25. Basu A, Saha D, Hembrom BP, Roy A, Naaz A. Comparison of palanosetron, granisetron and ondansetron as anti-emetics for prevention of postoperative nausea and vomiting in patients undergoing middle ear surgery. $J$ Indian Med Assoc. 2011; 109:327-329.

26. Bajwa SS, Bajwa SK, Kaur J, Sharma V, Singh $A$, Singh $A$, et al. Palonosetron: $A$ novel approach to control postoperative nausea and vomiting in day care surgery. Saudi J Anaesth. 2011; 5:19-24.

27. Park SK, Cho EJ. A randomized double blind trial of palonosetron compared with ondansetron in preventing post operative nausea and vomiting after gynaecological laparoscopic surgery. J Int Med Res. 2011; 39:399-407. 